\title{
Symbols of Individuation in E. S. Stevens's The Mountain of God
}

\author{
Cal E. Rollins
}

\begin{abstract}
E. S. Stevens's novel, The Mountain of God, is noteworthy because it records impressions of the Bahá'i community in 'Akká and Haifa in 1911. This essay uses elements of Jungian literary criticism to point out how the novel's two main characters are moving through the individuation process which could well lead them to acceptance of the teachings of Bahá'u'lláh. By employing symbolic language, Stevens demonstrates that these characters are evolving as a result of spiritual influences in the Holy Land. Jungian literary criticism, examining concepts developed by Carl G. Jung, attempts to explain the purpose of symbolic works of art in the psychic life of a society and their psychic significance. Such criticism seeks to add a new dimension to a piece of literature.
\end{abstract}

\section{Résumé}

Le roman de E. S. Stevens, The Mountain of God, est remarquable parce qu'il rapporte des impressions de la communauté bahá'íe à 'Akká et à Haiti, en 1911. Cet essai emploie des éléments de critique littéraire jungienne pour démontrer comment les deux personnages principaux du roman traversent un processus d'individuation qui pourrait bien les amener à accepter les enseignements de Bahá'u'lláh. Par l'utilisation d'un langage symbolique, Stevens démontre que l'évolution de ces personnages résulte des influences spirituelles en Terre Sainte. La critique littéraire jungienne, par l'examen de concepts développcs par Carl G. Jung, tente d'expliquer le but des oeuvres d'art symboliques dans la vie psychique d'une société donnée ainsi que leur signification psychique. Une telle critique vise à ajouter une nouvelle dimension à l'oeuvre littéraire.

\section{Resumen}

La novela de E. S. Stevens, The Mountain of God, es notable porque incluye impresiones de la comunidad Bahá'í en 'Akká y Haifa en 1911. Este ensayo usa elementos de la crítica literaria Jungiana para hacer ver que dos personajes centrales de la novela están atravesando por un proceso de individualización que los puede llevar a aceptar las enseñanzas de Bahá'u'lláh. Usando el lenguaje simbólico, Stevens demuestra que estos personajes están evolucionando como resultado de las influeneias espirituales en la Tierra Santa. La crítica literaria Jungiana, examinando conceptos desarrollados por Carl G. Jung, intenta explicar el propósito de obras de arte simbólicas en la vida psíquica de una sociedad así como sus sigificados psíquicos. Tal crítica busca añadir una nueva dimension a las obras literarias.

E S. Stevens's book, The Mountain of God, is "a significant historical document" ("Mountain," World Order 28) because it records impressions of the Bahá'í community in 'Akká and Haifa in 1911 and, most important, impressions of 'Abdu'l-Bahá. Stevens had apparently met 'Abdu'l-Bahá, and, based on the number of illuminated statements she makes about 'Abdu'l-Bahá, one may feel safe in saying that she was greatly attracted to his personality. Towards the end of the novel, one of Stevens's principals, Robert Underwood, after meeting 'Abdu'l-Bahá, says:

I think... that he is one of the sails of the world.... Why, some one — is it Maeterlinck? — once said that there were some rare spirits that carry the ship of humanity forward-beautiful ardent sails that fill with the winds of enthusiasm and genius and bear the boat forward. One need never be afraid of crowding too much sail on-for every white and wind-eager sail there are millions of heavy and prudent souls that provide the necessary ballast and keep the keel down in the waters of matter-of-fact. (Stevens, Mountain 360)

While it seems clear from the above statement that Stevens appreciated the influence of 'Abdu'l-Bahá on humanity, she failed to understand that his unique status, conferred by Bahá'u'lláh, placed 'Abdu'l-Bahá far beyond the influence of "heavy and prudent" souls. Although 'Abdu'l-Bahá was frequently pained by the imprudent conduct of some of the believers in Bahá'u'lláh, he was so wedded to his father that ballast by inadequate followers was a concept inappropriate to apply to him. It has been said of 'Abdu'l-Bahá, however, that he "walked the mystical path with practical feet."

Through the use of elements of Jungian literary criticism, this essay undertakes to point out significant symbols in The Mountain of God which suggest that, although during the course of the novel Robert Underwood and Sabra Greville do not declare their belief in Bahá'u'lláh, both of them in their unique ways are moving through a process of individuation that could well lead them to such a belief. Stevens offers the reader clues that her principal characters are, indeed, coming to terms with the new spiritual influences on their lives. She 
achieves this through use of symbolism. It is not the purpose of this study to comment on the merits of Stevens's novel as a literary piece. However, it is the writer's view that Stevens's The Mountain of God is the type of work of art about which Jung spoke when he said:

The unborn work in the psyche of the artist is a force of nature that achieves its end either with tyrannical might or with the subtle cunning of nature herself, quite regardless of the personal fate of the man who is its vehicle. (Jung, Spirit in Man 75)

\section{Jungian Literary Criticism}

Carl Jung's influence on literary criticism can be seen in part by the sudden wealth of anthologies of literature concerned with works of an archetypal nature. Perhaps the best use of Jungian literary criticism to date is Alex Aronson's Psyche and Symbol in Shakespeare. Aronson examines the plays of Shakespeare in terms of Jung's symbols of the collective unconscious and the process of individuation. Jung classifies literature into two modes-psychological and visionary. Psychological literature derives from human consciousness, joys, and sorrows, and is clarified and transfigured by the writer. According to Jung, in this group belong "all the novels dealing with love, the family milieu, crime and society, together with didactic poetry, the greater number of lyrics, and drama both tragic and comic" (qtd. in Aronson, Psyche). Jung says of the visionary mode:

It is something strange that derives its existence from the hinterland of man's mind, as if it had emerged from the abyss of prehuman ages, or from a superhuman world of contrasting light and darkness. It is a primordial experience which surpasses man's understanding and to which in his weakness he may easily succumb. (Qtd. in Aronson, Psyche)

Jung believes that symbolical artwork serves the purpose for a society that individual symbolic experience (a dream, for example) serves for a patient undergoing psychiatric therapy. Jungian literary criticism attempts to explain the purpose and significance of a symbolic work of art in the psychic life of a society. Such criticism can add a new dimension to a work of literary art. Examining a literary work using Jungian terms can show why the piece is structured as it is. Although the Jungian critic needs the tools of other schools of literary criticism to determine the movement and value of a work, the value of Jungian symbolism (in the context of analysis of a literary work) is to set the literature in a human context as a representative of the psyche. At the same time care, of course, must be taken that the literature's intrinsic worth as an art form is not abandoned. J. C. Cooper's An Illustrated Encyclopedia of Traditional Symbols and J. E. Cirlot's A Dictionary of Symbols, both recognized by Jungian literary critics as definitive collections of symbols, have been employed in this study.

\section{Individuation}

Calvin S. Hall and Vernon J. Nordby, in seeking to explain Jung's concept of individuation, say that every individual begins life in a state of undifferentiated wholeness (Primer 81). As a seed grows into a plant, with proper care, the direction of human growth is towards a fully differentiated, balanced, and unified personality (Primer 81). Jung felt that this unity is rarely ever reached except by a Jesus or a Buddha (Primer 82). Hall and Nordby comment:

This striving for self-realization or consummate selfhood is archetypal, that is to say, inborn. No one can avoid the powerful influence of this unity archetype, although what course its expression may take and how successful one may be in realizing the aim varies from person to person. (Primer 82)

They further explain:

Individuation is an autonomous, inborn process, which means that it does not require external stimulation in order to come into existence. The personality of an individual is destined to individuate just as surely as the body is destined to grow. But just as the body needs proper food and exercise for healthy growth, so the personality needs proper experiences and education for healthy individuation. (Primer 82-83)

It is only as a result of becoming conscious that a personality can proceed to individuate (Hall and Nordby, Primer 83). This is the ultimate goal of education, to make conscious that which is unconscious (Primer 83). For healthy development, all facets of the personality must be given the opportunity to become individuated. If one part of the personality is neglected, this neglected part will find abnormal ways of expressing itself (Primer 83).

Marie-Louise von Franz, while seeking to explain in lay terms principles of Jungian archetype, says of individuation: 
The actual process of individuation - the conscious coming to terms with one's own inner center (psychic nucleus) or Self-generally begins with a wounding of the personality and the suffering that accompanies it. This initial shock amounts to a sort of "call," although it is not often recognized as such. On the contrary, the ego feels hampered in its will or its desire and usually projects the obstruction onto something external. That is, the ego accuses God or the economic situation or the boss or the marriage partner of being responsible for whatever is obstructing it. ("Process" 166)

Von Franz further states that only one thing seems to help the person caught in the struggle for individuation

and that is to turn directly toward the approaching darkness without prejudice and totally naively, and to try to find out what its secret aim is and what it wants from you. ("Process" 167)

In Two Essays on Analytical Psychology, Jung says of individuation:

Individuation means becoming a single, homogeneous being, and, in so far as "individuality" embraces our innermost, last, and incomparable uniqueness, it also implies becoming one's own self. We could therefore translate individuation as "coming to selfhood" or "self-realization." (182)

\section{Symbolism} symbolism

J. C. Cooper, in her An Illustrated Encyclopedia of Traditional Symbols, says that the study of

is not mere erudition; it concerns man's knowledge of himself. Symbolism is an instrument of knowledge and the most ancient and fundamental method of expression, one which reveals aspects of reality which escape other modes of expression. (7)

She comments on the function of the symbol by stating that

the symbol does not merely equate; it must reveal some essential part of the subject to be understood; it contains the vast, ever-expanding realm of possibilities and makes possible the perception of fundamental relationships between seemingly diverse forms or appearances. (Encyclopedia 7)

Jung explains the essential features of his theory of symbolism thus:

The symbol is not a sign that veils something everybody knows. Such is not its significance; on the contrary, it represents an attempt to elucidate, by means of analogy, something that still belongs entirely to the domain of the unknown or something that is yet to be. (Hall and Nordby, Primer 116)

Hall and Nordby further comment:

...symbols are representatives of the psyche; they are projections of all aspects of man's nature. They not only try to express the stored-up racially and individually acquired wisdom of mankind but they can also represent levels of development that are predestinations of the individual's future status. Man's destiny, the future evolution of his psyche, is marked out for him by symbols. (Primer 117)

Explaining humanity's task in regard to the study of symbolism, they say:

...the knowledge contained in a symbol is not directly known to man; he must decipher the symbol by the method of amplification in order to discover its important message. (Hall and Nordby, Primer 117)

In Ego and Archetype, Edward F. Edinger clarifies the function of symbolism and comments on its absence in our society:

One of the symptoms of alienation in the modern age is the widespread sense of meaninglessness. Many patients seek psychotherapy not for any clearly defined disorder but because they feel that life has no meaning.... We seem to be passing through a collective psychological reorientation equivalent in magnitude to the emergence of Christianity from the ruins of the Roman Empire. Accompanying the decline of traditional religion there is increasing evidence of a general psychic disorientation. We have lost our bearings. (107) 
Edinger further comments that

the result is a pervasive feeling of meaninglessness and alienation from life. Whether or not a new collective religious symbol will emerge remains to be seen. For the present those aware of the problem are obliged to make their own individual search for a meaningful life. (Ego 107)

In explaining interpretation of symbolism in works of art, Edinger differentiates between abstract and subjective meaning in terms of symbolism when he characterizes subjective symbolism as

living meaning which does not refer to abstract knowledge but rather to a psychological state which can affirm life: It is this sense of the word we use when we describe a deeply moving experience as something meaningful. Such an experience does not convey abstract meaning, at least not primarily, but rather living meaning which, laden with affect, relates us organically to life as a whole. Dreams, myths, and works of art can convey this sense of subjective, living meaning which is quite different from objective, abstract meaning. (Ego 108)

Edinger summarizes the concept of symbolism when he states:

A symbol... is an image or representation which points to something essentially unknown, a mystery.... A symbol has a subjective dynamism which exerts a powerful attraction and fascination on the individual. It is a living, organic entity which acts as a releaser and transformer of psychic energy. (Ego 109)

\section{Analysis of the Novel}

Robert Underwood, because of the polo accident that robs him of the ability to walk without crutches, has, prior to coming to the Mountain of God-Mt. Carmel—suffered the pain and agony of the fight against helplessness and dependence. During his travels through Germany, Vienna, Budapest, Belgrade, Adrianople, and Constantinople, he has finally resolved "with grim determination, to learn to accustom himself to the life of dependence and helplessness, to exchange the role of onlooker for that of active participator" (Stevens, Mountain 3). Just as the hidden purpose of individuation demonstrates itself through dreams and fantasies of the unconscious, it often offers "a series of painful realizations of what is wrong with oneself and one's conscious attitudes" (Jung, Symbols 167). Underwood, then, is partially conscious of what his tasks will be.

Underwood's journey to the Holy Mountain begins in a boat. He is rowed by "four red-jerseyed, deeply bronzed boatsmen, bearing the legend 'Cook' in large white letters on their breasts" (Stevens, Mountain 1) towards the steamer on which he is to travel. Cirlot, in his discussion of the symbolism of the boat in Christian literature, comments:

The notion that it is essential first to learn to sail the sea of the passions in order to reach the Mountain of Salvation is the same as the idea mentioned earlier... For this reason Guenon suggests that "the attainment of the Great Peace is depicted in the form of sailing the seas...." (Dictionary 295)

Cirlot further comments that a great many references in literature testify that the boat is a symbol for the cradle rediscovered and the mother's womb (Dictionary 30). Cooper says of the ship symbolism that it represents setting out on the sea of life and crossing the waters of death (Encyclopedia 152). She states that in this connection ships share the bridge symbolism - crossing from this world into the next (Encyclopedia 152). Of the number four, Cirlot says that it is symbolic of the human situation, "of the external, natural limits of the 'minimum' awareness of totality, and, finally, of rational organization" (Dictionary 232). Cooper explains that the number four represents wholeness, totality, completion, solidarity, and order (Encyclopedia 115). According to Cirlot, the union of red and white is implicit in all mystical thought, while to Cooper the union represents purgatory or death (Dictionary 14; Encyclopedia 41).

Underwood, then, is being symbolically separated from the past. Another part of his life is in process. Stevens's symbols let the reader know that the character's journey is portentous and spiritual in nature. The fact that Underwood is taken by boat to the vessel out at sea is a symbolic device to make the reader conscious of the psychic development about to take place.

It is significant to note that Sabra Greville is also brought to the sailing vessel by the boatsmen. Underwood observes that the boat carrying Sabra is the fourth to approach. Both of the characters are about to embark upon a journey of meaning to their future lives. Their travel to the Holy Land by sea - the symbol of dynamic forces and of transitional states, the sum of all possibilities - takes on a spiritual dimension. For Underwood, the journey leads from pain and disillusionment to the Master, 'Abdu'l-Bahá. For Sabra Greville, it 
leads from that same negative state to acknowledgement of the need for self-abnegation through service to another human being.

At the outset of Underwood's journey, he is lifted on board by a young Syrian "with a full round face, a girl's complexion, and a naive anxiety to be useful" (Stevens, Mountain 2). Stevens calls attention in a number of places to Underwood's observation of Noureddin, the young Persian who is later to help him. Underwood is struck by his grave and serene face, as if Noureddin is possessed of an inner knowledge. At one point he is lulled as in the Arabian Nights by Noureddin's beauty (Mountain 146). At another, Underwood sees him as a graceful animal and speaks to him almost as he would have spoken to a female (Mountain 146). At yet another place, Underwood describes Noureddin's hands as being as gentle as a woman's. Stevens is persistent in her image of androgynous youth assisting Underwood to heightened consciousness. According to Cooper, androgyny universally symbolizes the reunion of primordial male-female forces, of heaven and earth, the two becoming the One, the all-father, the all-mother (Encyclopedia 12). According to Jung, androgyny is associated with the anima, personification of a male's unconscious. In the process of individuation, coming to terms with the anima is, for a man, the second step after recognizing and accommodating one's shadow. The anima (animus in females) is the inward face of a male psyche. According to Jung's concept of the anima, if a man exhibits only masculine traits, his feminine traits remain unconscious, undeveloped, and primitive (Hall and Nordby, Primer 46-47). This gives the unconscious a quality of weakness and impressionability (Hall and Nordby, Primer 47). Stevens signals the reader that Underwood, through the individuation process, is soon to deal with his anima, represented by Sabra Greville. Hall and Nordby say of Jung's view:

...man inherits his image of woman, and he unconsciously establishes certain standards that will strongly influence his acceptance or rejection of any specific woman. (Primer 47)

Underwood at first dislikes Sabra Greville because of her self-absorption and naive egotism. Her physical vitality is painful to him:

He was looking at her dark animated face, her movements which spoke of perfect health, her undefinable air of joyous vitality. And it was with dull envy. Whenever he was with her, he realised the value of physical strength; the intense beauty of physical things; and was filled with an impatient hunger which could never be satisfied. He almost resented her for reminding him of his own lack of what she possessed so abundantly. The very pleasure which she showed in the almond-blossom seemed to him for the moment symbolical of the frank pleasure that she took in the things which belonged to a body perfectly attuned to respond to everything in Nature. He was the broken instrument. (Stevens, Mountain 81-82)

When he discovers her affair with Schmidt Pasha, any hopes Underwood might have projected upon Sabra Greville are abolished. Stevens states:

He realised, as he had never realised since his accident, that the role of active participator in life had been taken from him. The newborn strength to which he had trusted had failed him utterly at the first call he had made upon it. (Mountain 210)

As the novel develops and ends, Underwood comes to terms with his anima and recognizes his love for Sabra Greville and even seeks to shield her from pain. Her capacity for suffering "and for inflicting suffering, her reckless egotism, and her power of self-immolation, had become part of his crippled life" (Stevens, Mountain 376-77).

Sabra Greville represents for Underwood the romantic and aesthetic level of the anima. His coming to terms with her allows him to accommodate and assimilate the feminine aspects of his unconscious so that he is able to develop his own inner, unique personality.

For a woman, coming to terms with her animus properly is also crucial. When a woman succumbs to the negative animus, she becomes opinionated instead of reflective; she is not logical. An animus-possessed woman is concerned with power. When anima and animus meet, the relationship is always full of animosity. Some of the more negative characteristics of the animus are brutality, recklessness, empty talk, and silent, obstinate, evil ideas. On the positive side, the animus gives to a woman's consciousness the capacity for reflection, deliberation, and self-knowledge. Sabra Greville's journey leads her to an understanding of selflessness. Her continual bouts with the concept of the "Will of God" through the conflict with and loss of her lover, Schmidt Pasha (because of his eventual conversion to the Faith of Bahá'u'lláh) and prior to that conversion, with her acceptance of the higher moral principle, led her to a new life. She accepts her lover's commitment to his pregnant wife and her own duty to her estranged husband lying ill somewhere in South Africa, the product of a dissolute and profligate life. When Underwood admonishes her not to sacrifice herself to 
a man he characterizes as a drunken brute (Stevens, Mountain 378), she exclaims: "I'll be better employed in fighting his devils than mine. It will be almost a healthy occupation" (Mountain 378). Through these acts of awareness, Stevens makes it clear that Sabra has begun to come to terms with her psychic nucleus.

By coming to the Holy Land, Sabra Greville has broken with the past—with England—although at one point she longs to be back there, away from the country

which laid such haunting and insistent hands on her soul, which was always promising but never fulfilling - away back to the past with which she had so cheerfully and uncompromisingly broken. (Mountain 151-52)

Before her journey to the Holy Land, she answers the call associated with the beginning of a heroic journey. Sabra experiences the deadly boredom that Jung associates with the initial stage of the individuation process. She experiences mental and physical unrest. Stevens says of Sabra's past relationships with men in England:

She could not explain now, even, why the sudden impatience of Western life had seized her, why even her unconventional and pleasant friendship with these men had suddenly seemed ineffably banal and provincial. Even her carefully won freedom had become stale to her. A craving had been on her for a more natural life, for sun, for the land where her first childhood had been spent. And when the opportunity had occurred she had seized it-decided to go in a week, and left with no regrets. (Mountain 152)

Both she and Underwood had broken with the past and begun the individuation quest. Sabra turns the page on her memory of the bitter chapters behind her and Underwood is

sent forth, a naked personality, to cope with the circumstances which were entirely the reverse of all that had come before. And his subconscious self had leapt again into being, crying aloud its assurance of a deliberate Fate, a ruthless hand, acting with purpose and with callous and terrible intelligence. This hereditary inner consciousness of his, moreover, called this fate the hand of God. His reason might contradict, bitterly, mockingly; but, nevertheless, something within him repeated with inevitable surety and conviction, "This is God, this is God!" (Mountain 70)

Edinger points out that at a certain stage in one's psychological development (primarily after an intense experience of alienation) the "ego-Self axis" breaks into conscious view. The ego becomes aware of a transpersonal center to which the ego is subordinate (Ego 79). Edinger suggests that whenever we encounter a divine agency "which assists, commands, or directs, we can understand it as an encounter of the ego with Self" (Ego 70). Underwood is conscious of the motivating forces at play upon him which later lead to a discovery of 'Abdu'l-Bahá and the teachings of Bahá'u'lláh.

To strengthen further the mystical nature of Underwood's call, Stevens makes his entrance into the holiest of lands as in a dream; a feeling of "unreality possessed him, or rather dispossessed him, for the sense of detachment was very strong." Sabra Greville states, in speaking of the mystical effect of Mt. Carmel upon the visitor: "There is something in the air, they say, which makes one able to understand hidden things — something which awakes the spiritual nature." They both reside in an atmosphere rarified by Spiritual Presence.

Of particular import in an examination of The Mountain of God is the fact that the novel, along with incorporating the image of the sacred mountain and the sea throughout its development, not only begins with those images but also ends with them. Cirlot suggests that all symbolic interpretations of mountains (to which he has been exposed) have to do with attainment to a higher good or more lofty state of being. Of special note is the Iranian concept of the Cosmic Mountain, which gradually grows wider towards its base, like the Cosmic Tree and, hence, becomes the center of the world (Dictionary 219). Cooper states that on the spiritual level mountain tops represent the state of full consciousness. Pilgrimages up sacred mountains symbolize aspiration, renunciation of worldly desires, attaining to the highest states of consciousness (Encyclopedia 110).

Mt. Carmel, through Robert Underwood's eyes

was the presiding genius of the place. The town lay nursed in her mighty lap, her long flanks stretched away to the sea on the north and south and west, the sun disappeared behind her long ridge a full hour before the sunset rosied the sky and set the snows of Mount Hermon, her far white sister, on fire on the other side of the bay. (Stevens, Mountain 26)

He is obviously attracted to the forces on the Mountain of God, and his eventual walk on the Mountain symbolizes his having attained the object of his quest. In his preoccupation with the Mountain, he states to Whitby, a recent Bahá'í convert of English background: 
I can't think why Carmel should be called the Mountain of God....Hermon, across the bay, seems to me infinitely more beautiful, more mysterious. It lies distant, it is veiled by clouds, there is something of the beauty of unapproachableness about it; its eternal snows, its height, its power of appearing and disappearing according to the weather, make it far better adapted to the name. Carmel is scarcely more than a hill; it is so devoid of mystery that in this atmosphere you can see almost every blade of grass, and there are no shadows or mists upon it. (Stevens, Mountain 32-33)

Whitby's retort is that God is not expressed by mist and indistinctness. He is "the Father of Lights, with whom is no variableness nor shadow of turning" (Stevens, Mountain 33).

God's Holy Mountain is clearly the center of Underwood's new world, and his journey ends there. At the end of the narrative when he sees Sabra Greville off at the dock, he faces the unknown; yet, the Persian Bahá'ís are waiting for him on the quay. The reader has no reason to believe that his suffering, his awareness, his friendship with the Bahá'ís in the Holy Land, and his understanding of the station of 'Abdu'l-Bahá will not culminate in his becoming a Bahá'í.

This theory of the ultimate acceptance of the object of Underwood's quest is further strengthened by the fact that even before he comes to terms with his feelings for Sabra Greville (the representation of his anima), he has encountered three aspects of his shadow, that dark, opposite side of ourselves we usually prefer to hide from others, and even from ourselves. Hall and Nordby say of the shadow:

The shadow contains more of man's basic animal nature than any other archetype does. Because of its extremely deep roots in evolutionary history, it is probably the most powerful and potentially the most dangerous of all the archetypes....

In order for a person to become an integral member of the community, it is necessary to tame his animal spirits contained in the shadow. This taming is accomplished by suppressing manifestations of the shadow and by developing a strong persona which counteracts the power of the shadow. (Primer 48-49)

Hall and Nordby further comment that people who suppress the animal side of their nature may become civilized, but they do so at the expense of decreasing the motive power for spontaneity, creativity, strong emotions, and deep insights. Hall and Nordby state that a shadowless life tends to become shallow and spiritless. They continue:

When the ego and the shadow work in close harmony, the person feels full of life and vigor. The ego channels instead of obstructing the forces emanating from the instincts. Consciousness is expanded and there is a liveliness and vitality to mental activity. (Primer 49)

Of shadow conflict, Hall and Nordby state:

We have said that the shadow is responsible for one's relations with the same sex. These relations may be either friendly or hostile depending upon whether the shadow is accepted by the ego and becomes incorporated harmoniously into the psyche, or whether it is rejected by the ego and banished to the unconscious. Men tend to project their rejected shadow impulses on other men so that bad feelings often arise between males. The same is true for women. (Primer 50-51)

Von Franz says of shadow conflict:

When an individual makes an attempt to see his shadow, he becomes aware of (and often ashamed of) those qualities and impulses he denies in himself but can plainly see in other people....

In dreams and myths...the shadow appears as a person of the same sex as that of the dreamer. ("Process" 168)

Both Magner (Underwood's manservant) and Whitby represent the positive shadow to Underwood; while Schmidt Pasha, Sabra Greville's lover, represents the negative. Recognition of the shadow follows the call and precedes the recognition of the anima. Underwood says of Magner:

Oddly enough, Magner was the one rock in this sea of vague distrust and resentment upon which his soul could rest. Magner represented calm, cool common sense. Magner, imperturbable, self-contained, without a sense of humour, was the one permanent and solid thing in his ever-changing horizon-the 
serio-comic link between his past and his new personality. His people, Kitty, his men-friends, his poloponies, his prints, his very habits of thought and body, had been swept past on the current. Magner was stable. (Stevens, Mountain 70)

Magner serves to point Underwood towards religion as a course of action when he, as a great surprise to Underwood, requests permission to attend the English Church. Almost as though he divines Underwood's condition of existential dread he states, "Without wishing to be disrespectful, sir, I've often wondered, so to speak, if the Almighty isn't a little bored Himself" (Stevens, Mountain 71). Just before Underwood is to have the encounter with Sabra Greville and Schmidt Pasha which brings his emotions regarding her to the forefront, Magner has stated a very simple fact to him - that he is getting much better. With this statement Underwood has a "sudden bound of hope." As he climbs into the carriage bound for his fatal discovery that Sabra is physically and emotionally involved with Schmidt Pasha, "Magner's words came back to him, and the slender flame of hope flickered anew."

The purpose of Magner in the novel is to give Underwood someone onto which to project and from whom to draw strength. Like Magner, Whitby (another shadow figure) understands the psychical crises through which Underwood has passed. When Whitby notes "the splendid proportions of the man, his breadth of chest, and muscular build," he sees Underwood's helplessness as grotesque. Secretly, "and with a pulse of joy," he says, "But the man is fortunate, though he doesn't know it." Whitby smiles to himself because he knows what is to be Underwood's ultimate end. In a prophetic letter to Underwood on the eve of Whitby's departure for Persia, Whitby alludes to Underwood's eventual conversion to the Bahá'í Cause by stating that there was no escape. He concludes:

I have said I envy you; because, if you only knew it, the wall isn't solid at all—and there's all the universe on the other side! God grant that you will know what I mean sooner or later. (Stevens, Mountain 107)

Whitby has been commanded by 'Abdu'l-Bahá to do 'Abdu'l-Bahá work in Tehran. This fact is titillating to Underwood, and he is sorry that Whitby is gone with the secret- "more sorry than he could say. So the mysterious summons or commands had been given. By whom? Through whom?" Whitby, as a positive shadow figure, gives Underwood what he needs to know at the second stage of his move along the individuation process. Underwood's deep dislike, distrust, and jealousy of Schmidt Pasha culminate in his awareness of Pasha's attachment to the Bahá'í Faith. This third aspect of the shadow but serves to strengthen the direction of the other two.

Having realized the first three stages of the individuation process, Underwood is prepared for the final stage - realization of the self. For Jung, the self expresses the unity of the personality as a whole and designates the entire range of the psychic phenomena in human beings. Edinger states in "An Outline of Analytical Psychology" the archetype of the self many times appears as a process of centering or as a process involving the union of opposites (7). Hall and Nordby say of the self:

The self is the central archetype in the collective unconscious, much as the sun is the center of the solar system. The self is the archetype of order, organization, and unification; it draws to itself and harmonizes all the archetypes and their manifestations in complexes and consciousness. It unites the personality, giving it a sense of "oneness" and firmness. (Primer 51)

In explaining the development of the self as the final stage in the individuation process, Hall and Nordby continue:

As Jung points out, the self archetype does not even become evident until about middle age, since the personality must become fully developed through individuation before the self can become manifest with any degree of completeness. (Primer 52)

Underwood's meeting with 'Abdu'l-Bahá, who was extolled by Bahá'u'lláh as the Mystery of God, symbolizes Underwood's recognition and realization of the self. Prior to that meeting certain truths have been revealed to him. Stevens says of Underwood:

He only knew that, quite abruptly, his feverish desire after the old physical health had left him, that he no longer beat his wings against the bars; and that a contentment, a feeling of well-being, a sense of communion with the spiritual force of the world, filled his entire being at times, leaving him calmed and satisfied. (Mountain 238) 
Sabra Greville recognizes in him some of the same quiet awareness demonstrated by the mannerisms of Whitby and Noureddin. Underwood has found happiness and concludes that a state of felicity is merely adjusting oneself to one's environment. Stevens states of Underwood's new-found views:

It seemed to Underwood that day, amid the Syrian sunshine and clean air, that he had found, unconsciously, the secret of that harmony. Something within him, very humbly and gladly, sang and praised God for its existence. He could no more explain the reason of this than of his own being. But there was a larger hope in him than was bounded by his recovery, a bigger horizon than was held by the skyline of himself. Whether that horizon was called the Malekoot of God, as the Persians called it, whether it was simply the instinctive lifting of himself into the unknown God which sits behind every human consciousness he could not tell, and would not dare to define. (Mountain 289)

It is curious to note that 'Abdu'l-Bahá sent Underwood fruit and flowers with his greetings. Cirlot states that fruit in traditional symbolism represents the Origin and stands for earthly desires (Dictionary 115). Cirlot further comments that the symbol of the flower stands for transitoriness and for beauty (Dictionary 115). Cooper sees fruit as representing immortality and the essence, the culmination, the result of one state and the seed of the next (Encyclopedia 72). Cooper also comments that the flower symbol takes on the symbolism surrounding the cup. She states: "In the bud the flower is potentiality: in opening and expanding from the centre outwards it depicts development in manifestation..." (Encyclopedia 70).

When Underwood meets the Master for the first time on the road, at 'Abdu'l-Bahá's summons, Underwood's realization of the self is complete. Stevens describes that recognition:

Before him stood the figure with the iron-grey cloak. His beard was white, his hair, which was long, was doubled up beneath his turban, from which a snowy strand or two escaped. Underwood met the penetrating and kindly gaze of a pair of blue eyes set beneath overhanging eyebrows. It was one of the most commanding countenances that he had ever seen. Strength was in every line of it. The transparency of the skin showed the spirit triumphing over a somewhat tired body; his erect, dignified carriage, keen self-possession, was continual and complete. The nose was hooked, and very cleanly chiselled; there were lines of gentle humour about his eyes. The whole aspect of the man gave an impression of indomitable will, mingled with something difficult to define, which made him lovable. Spirituality is an abused word, but it might stand for it. (Mountain 299)

For Sabra Greville the process of individuation is set at an entirely different pace from that of Underwood's. Her shadow figure appears in the guise of Niguar Khanoum, who exhibits Sabra Greville's positive potentialities. Stevens says of Sabra's feelings towards Niguar Khanoum:

She had a genuine liking for Niguar Khanoum, but the attraction she felt was half curiosity.... She had a sure inner knowledge of what would impress Niguar Khanoum, and it amused her to touch the springs of femininity and luxury in this secluded woman's heart. She found that she had instinctive understanding, too, of the barbarous child that underlay the exterior of Parisian clothes and French conversation. The barbarous child existed in her too, to a greater extent perhaps than in Niguar Khanoum herself. The difference was that Sabra knew of its existence within her soul, whereas Niguar was not introspective enough to understand herself. (Mountain 119-20)

Sabra comes to realize she has never been able to make Schmidt Pasha more than physically unfaithful to Niguar Khanoum. She thinks:

And if hitherto she had not succeeded in establishing an ascendancy, what would happen now that Niguar was pregnant? She knew how much that would mean in Schmidt Pasha's eyes, and that, to an Oriental, motherhood gives a woman an honour and value which no amount of physical or mental attraction can rival. And that honour could never be hers.... (Stevens, Mountain 248)

As soon as this revelation comes upon her, Sabra Greville is able to begin to resolve the conflict of the animus which she has projected upon Schmidt Pasha. She comes to see that there is a great gap between her and Pasha - a gap that does not exist between him and his wife.

Sabra had already sought the answer to her predicament when she muses:

Why did this man, at best a mere interlude, obsess her? She was angry with herself that she should care.... She, on the other hand, had felt more tender than she had ever felt to a lover before. There was 
something of the boy about him, something primitive, which touched an entirely new chord in her being. (Stevens, Mountain 194)

When she follows Pasha, who is on a secret political mission, to 'Akká and saves him from death, she plays out the last of her hopes. Upon his eventual return to Haifa, he accepts the teachings of Bahá'u'lláh, and she wonders what will be the effect of these teachings upon their relationship. As she intuits, Schmidt Pasha's newfound faith makes both their relationship and his political activity impossible. 'Abdu'l-Bahá is sending Pasha and his wife to Persia. Before bidding her goodbye, with a good deal of religious fervor, Pasha predicts that she will one day declare her belief in Bahá'u'lláh. Tenderly he leaves her to face herself.

It is interesting that twice Sabra Greville is in the vicinity of 'Abdu'l-Bahá, but neither time does she meet him. When Underwood is called to 'Abdu'l-Bahá on the ramparts, Sabra, though nearby, is not included in that interview. Prior to that time, Underwood has invited her to go to 'Akká where they will meet the Master. Sabra does not want to go because she fears Schmidt Pasha might come back from his mission and miss her should he want her. Although she later changes her mind and goes with Underwood to 'Akká, it is only because she knows that Schmidt Pasha might also be there. Stevens is telling the reader that Sabra Greville is not yet ready for the last stage in her psychic development. 
Despite all of Sabra Greville's exposure to the Bahá'í environment and to the Bahá'í teachings, she does not seem to demonstrate an inclination to accept a new belief. However, her decision to go to South Africa to care for her demonic husband is in keeping with the processes in her life that need to become more fully developed. Underwood's farewell to her is prophetic:

"This reminds me of our first meeting," she said.... "I wish it weren’t good-bye."

"I've a feeling that it may not be for long," he answered. "Who knows what the days and nights may bring us!" (Stevens, Mountain 380)

Although Sabra Greville's work is unfinished, the reader is comforted by the words of 'Abdu'l-Bahá in reference to Mt. Carmel:

This mountain is a holy mountain: it has always been sanctified. The prophets have always loved it. Christ has trodden on its paths; Elijah lived upon it. The wind is sweet on it, the flowers are many, the view is wonderful. When you come up the mountain many fragrances reach you; the pure air gladdens you; the beauty refreshes you. So the mind is made single, the thoughts are purified; the spirit turns to God. (Frontispiece, Mountain)

\section{Works Cited}

Aronson, Alex. Psyche and Symbol in Shakespeare. Bloomington: Indiana University Press, 1972.

Cirlot, J. E. A Dictionary of Symbols. New York: Philosophical Library, 1962.

Cooper, J. C. An Illustrated Encyclopedia of Traditional Symbols. London: Thames and Hudson, 1978.

Edinger, Edward F. Ego and Archetype. Baltimore: Penguin Books, 1974.

"An Outline of Analytical Psychology." Quadrant: Notes on Analytical Psychology. Reprint 1. New York: The C. G. Jung Foundation for Analytical Psychology, 1968.

Hall, Calvin S., and Vernon J. Nordby. A Primer of Jungian Psychology. New York: New American Library, 1973.

Jung, Carl G. "On the Relation of Analytical Psychology to Poetry." The Spirit in Man, Art, and Literature. Trans. R. F. C. Hull. Bollinger Series 20. Vol. 15. New York: Pantheon Books, 1966.

—. Two Essays on Analytical Psychology. Trans. R. F. C. Hull. New York: World, 1953.

Jung, Carl G., et al. Man and His Symbols. Garden City: Doubleday, 1964.

“Mountain of God, The.” World Order 4.3 (Spring 1970):28-52.

Stevens, E. S. The Mountain of God. London: Mills \& Boon, 1911.

Von Franz, Marie-Louise. "The Process of Individuation.” In Man and His Symbols, edited by C. G. Jung. Garden City: Doubleday, 1964. 